\title{
Analisis Penentuan Sektor Unggulan di Kabupaten Sumedang Provinsi Jawa Barat
}

\author{
Fahrul Alam Masruri ${ }^{1)}$, Cahyono ${ }^{1)}$, Nugrahana Fitria Ruhyana ${ }^{2)}$ \\ STIE Sebelas April Sumedang ${ }^{1)}$ \\ Badan Perencanaan Pembangunan Penelitian dan Pengembangan Daerah Kabupaten Sumedang ${ }^{2)}$ \\ fahrulalam@stie11april-sumedang.ac.id \\ cahyono@stie11april-sumedang.ac.id \\ nugrahana@gmail.com
}

\begin{abstract}
Abstrak
Tujuan penelitian ini adalah menganalisis sektor unggulan yang potensial untuk dikembangkan di Kabupaten Sumedang. Selama10 tahun terakhir, perekonomian Sumedang didominasi oleh 3 sektor utama, yaitu sektor pertanian, kehutanan, dan perikanan, sektor industri pengolahan, dan sektor perdagangan. Dari ketiga sektor tersebut dan 14 sektor lainnya, belum diketahui mana yang paling unggul dan berpotensi menjadi penggerak utama perekonomian Sumedang. Metode penelitian ini menggunakan sequential explanatory method, diawali analisis kuantitatif dengan pendekatan LQ, Shift Share dan overlay, kemudian hasilnya dilanjutkan dengan pendekatan kualitatif dengan melakukan Focus Group Discussion bersama stakeholder pembangunan ekonomi di Kabupaten Sumedang. Hasil perhitungan LQ menunjukkan bahwa terdapat 11 sektor yang terkategori sektor basis di Sumedang, sementara dari analisis Shift Share hanya terdapat 2 sektor yang mampu tumbuh lebih cepat dan memiliki daya saing dibandingkan dengan sektor yang sama di Jawa Barat, yaitu sektor konstruksi dan sektor jasa keuangan dan asuransi. Adapun dari hasil FGD, sektor pertanian, kehutanan, dan perikanan dinilai memiliki potensi menjadi penggerak utama perekonomian Sumedang karena merupakan sektor basis, memiliki daya saing, dan sesuai dengan kondisi kekinian yaitu menjadi sektor yang resisten ketika terjadi pandemi covid-19, sebagai penopang ketahanan pangan, jaring pengaman sosial alamiah melalui serapan tenaga kerja yang besar, dan penguat aktivitas ekonomi perdesaan.
\end{abstract}

Kata Kunci: Sektor unggulan, potensi ekonomi, Kabupaten Sumedang

\begin{abstract}
The purpose of this study was to analyze the potential leading sectors to be developed in Sumedang Regency. During the last 10 years, Sumedang's economy has been dominated by 3 main sectors. Of the three sectors and 14 other sectors, it is not yet known which one is the most superior and has the potential to be the main driving force of Sumedang's economy. This research method uses a sequential explanatory method, starting with $L Q$ approach, Shift Share and overlay, then the results are followed by a qualitative approach by conducting a Focus Group Discussion with economic development stakeholders in Sumedang Regency. There are 11 sectors that are categorized as basic sectors, but there are only 2 sectors that are able to grow faster and have competitiveness compared to the same sector in West Java, namely the construction sector and the financial services sector and insurance. The agriculture, forestry and fisheries sectors are considered to have the potential to be the main driver of the Sumedang economy because it is a basic sector, has competitiveness, being a resistant sector during the Covid-19 pandemic, as a support for food security, a natural social safety net, and strengthening rural economic activity.
\end{abstract}

Keywords: Leading sector, economic pottencial, Sumedang Regency

\section{PENDAHULUAN}

Arah perkembangan ekonomi makro secara regional ditunjukkan untuk meningkatkan pertumbuhan ekonomi, menciptakan kesempatan kerja dan menjaga stabilitas harga agar daya beli masyarakat bisa tidak turun. Untuk mencapat tujuan perekonomian makro tersebut berbagai upaya dilakukan khususnya melalui upaya-upaya peningkatan pertumbuhan ekonomi baik secara agregat maupun berdasarkan sektoral/kategori.
Agar sasaran peningkatan pembangunan ekonomi melalui pertumbuhan ekonomi bisa dicapai, seringkali daerah melakukan strategi yang didasarkan atas penentuan sektor-sektor unggulan (Novita \& Gultom, 2017).

Kemampuan pemerintah daerah untuk melihat sektor yang memiliki keunggulan dan kelemahan di wilayahnya menjadi semakin penting. Sektor yang memiliki keunggulan, memiliki prospek yang lebih 
baik untuk dikembangkan dan diharapkan dapat mendorong sektor-sektor lain untuk berkembang.

Potensi daerah satu dengan daerah lainnya pasti berbeda-beda. Hal tersebut terkait dengan karakteristik masing-masing daerah sehingga dalam upaya mencapai tujuan pembangunan ekonomi daerah, kebijakan utama yang perlu dilakukan adalah mengusahakan semaksimal mungkin agar prioritas pembangunan daerah sesuai dengan potensi yang dimiliki daerah (Yulianita, 2009). Hal ini juga pernah dikemukakan oleh Arsyad (2005), masalah pokok dalam pembangunan daerah adalah terletak pada penekanan terhadap kebijakan-kebijakan pembangunan yang didasarkan pada kekhasan daerah yang bersangkutan (endogeneous development) dengan menggunakan potensi sumberdaya manusia, kelembagaan, dan sumber daya fisik secara lokal (daerah).

Pertumbuhan Produk Domestik Regional Bruto (PDRB) tidak lepas dari peran sektor atau lapangan usaha. Semakin besar sumbangan atau peran suatu sektor atau lapangan usaha dalam pembentukan PDRB, maka semakin besar pula pengaruh sektor tersebut dalam perkembangan perekonomian suatu daerah.

Di Indonesia, pada awalnya sektor pertanian memiliki kontribusi cukup besar jika dibandingkan dengan sektor lainnya pada perekonomian wilayah. Meskipun sektor pertanian masih sangat dominan, tetapi kontribusinya terhadap PDRB umumnya mengalami penurunan. Sebaliknya sektor lain seperti jasa-jasa dan perdagangan, hotel dan restoran menunjukkan peningkatan kontribusi secara perlahan-lahan (Sapriadi \& Hasbiullah, 2015). Demikianlah kondisi perekonomian mengalami proses transformasi dari ketergantungan terhadap sektor pertanian kepada sektor-sektor lainnya. Di Kabupaten Sumedang, penggerak utama perekonomian dalam sepuluh tahun terakhir yang awalnya didominasi sektor pertanian, kehutanan, dan perikanan sudah mulai bergeser ke sektor industri pengolahan sebagai penyumbang PDRB terbesar di 2019 (Gambar 1.).

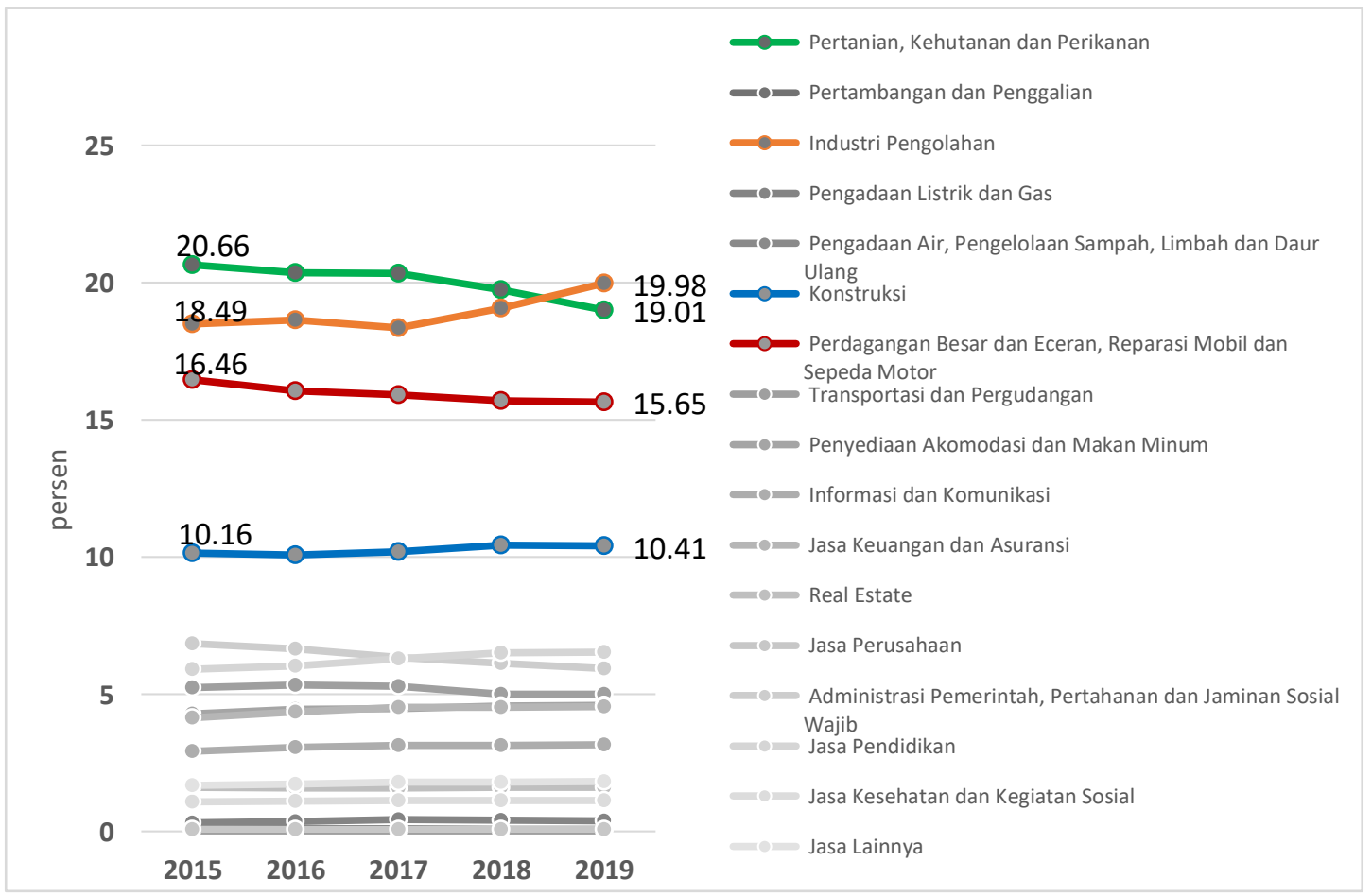

Sumber: BPS Kabupaten Sumedang, 2020

Gambar 1. Kontribusi Lapangan Usaha pada PDRB Kabupaten Sumedang, Tahun 2015 - 2019

Dari data tren kontribusi sektoral pada PDRB Kabupaten Sumedang di atas, sektor pertanian masih cukup strategis mengingat perannya dalam penyerapan tenaga kerja dan sumber utama penghidupan masyarakat di Kabupaten Sumedang
(Gambar 2.). Meskipun terjadi pergeseran dari sektor tersebut ke sektor perdagangan di 2019, namun proporsi penduduk dengan mata pencaharian di sektor pertanian, kehutanan, dan perikanan masih sangat tinggi. 


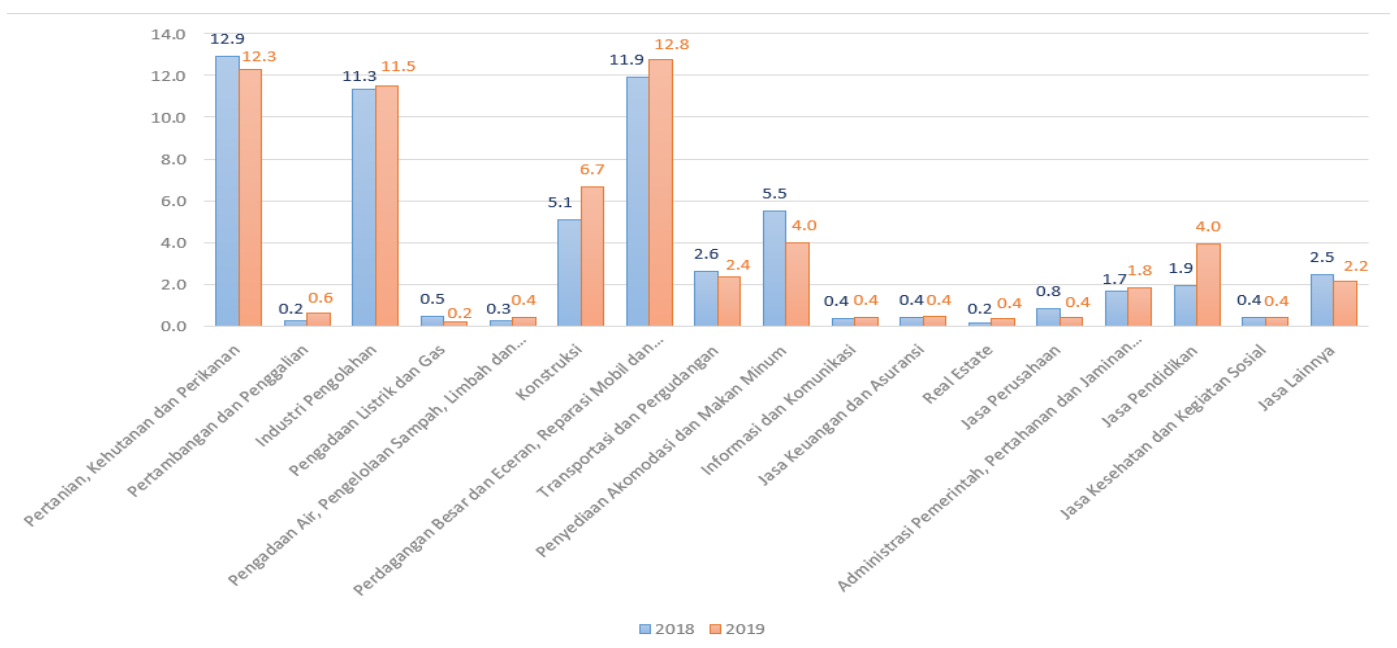

Sumber: Survey Angkatan Kerja Nasional Tahun 2018 dan 2019 (diolah)

Gambar 2. Proporsi Angkatan Kerja pada Setiap Lapangan Usaha di Kabupaten Sumedang Tahun 2018 dan 2019

Berdasarkan kondisi di atas, timbul pertanyaan apakah perubahan kontribusi sektoral yang terjadi telah didasarkan kepada strategi kebijakan pembangunan yang tepat, yaitu strategi yang memberikan dampak yang optimal bagi pertumbuhan ekonomi, peningkatan lapangan pekerjaan, dan peningkatan kesejahteraan penduduk. Karena untuk melaksanakan pembangunan dengan sumberdaya yang terbatas, sebagai konsekuensinya harus difokuskan kepada pembangunan sektor dan komoditas unggulan yang memberikan dampak pengganda (multiplier effect) yang besar terhadap sektor-sektor lainnya atau perekonomian secara keseluruhan. Oleh karena itu, diperlukan informasi terkini mengenai sektor-sektor ekonomi unggulan yang dapat dikembangkan di Kabupaten Sumedang.

Perencanaan pengembangan sektor unggulan diharapkan dapat membantu untuk meningkatkan perekonomian daerah untuk diarahkan sebagai area pengembangan sektor perekonomian (Adhitama, 2012). Penelitian ini mencoba menggambarkan sektor-sektor unggulan yang memiliki konsentrasi tinggi dalam struktur perekonomian Kabupaten Sumedang dan pergeseran sektoral dibandingkan dengan daerah acuan, dalam hal ini Provinsi Jawa Barat, sehingga dapat dijadikan pertimbangan dalam perumusan kebijakan dan perencanaan pembangunan di Kabupaten Sumedang.

\section{KAJIAN PUSTAKA}

\section{Teori Pertumbuhan Ekonomi}

Setiap negara atau wilayah perlu melihat sektor atau komoditi apa yang berpotensi besar dan dapat dikembangkan dengan cepat, baik karena potensi alam maupun karena sektor itu memiliki competitive advantage untuk dikembangkan (Samuelson dalam Robinson, 2005). Perkembangan sektor tersebut akan mendorong sektor lain turut berkembang sehingga perekonomian secara keseluruhan akantumbuh.

Teori pertumbuhan wilayah menganalisis suatu wilayah sebagai suatu sistem ekonomi terbuka yang berhubungan dengan wilayah-wilayah lain melalui arus perpindahan faktor-faktor produksi dan pertukaran komoditas. Pembangunan dalam suatu wilayah akan mempengaruhi pertumbuhan wilayah lain dalam bentuk permintaan sektor tersebut untuk wilayah lain yang akan mendorong pembangunan wilayah tersebut atau suatu pembangunan ekonomi dari wilayah lain akan mengurangi tingkat kegiatan ekonomi di suatu wilayah serta interrelasi.

Menurut Sirojuzilam dalam Amalia (2012), pertumbuhan ekonomi dapat dinilai sebagai dampak kebijaksanaan pemerintah, khususnya dalam bilang ekonomi. Pertumbuhan ekonomi merupakan laju pertumbuhan yang dibentuk dari berbagai sektor ekonomi yang secara tidak langsung menggambarkan tingkat pertumbuhan yang terjadi dan sebagai indikator penting bagi daerah untuk mengevaluasi keberhasilan pembangunan.

Pertumbuhan regional dapat terjadi sebagai akibat dari penentu-penentu endogen ataupun eksogen, yaitu faktor-faktor yang terdapat di dalam daerah yang bersangkutan atau pun faktor-faktor di luar daerah atau kombinasi dari keduanya (Hilmi et al., 2014). Penentu endogen, meliputi distribusi faktor-faktor produksi seperti tanah, tenaga kerja, dan modal sedangkan penentu eksogen adalah tingkat permintaan dari daerah lain terhadap komoditi yang dihasilkan oleh daerah. 


\section{Sektor Basis}

Sektor basis menjadi tulang punggung perekonomian daerah karena mempunyai competitive adventage yang cukup tinggi. Sedangkan sektor non basis adalah sektor-sektor lainya yang kurang potensial tetapi berfungsi sebagai penunjang sektor basis atau service industries (Nasution, 2020). Kegiatan basis merupakan kegiatan yang melakukan aktivitas yang berorientasi ekspor (barang dan jasa) ke luar batas wilayah perekonomian yang bersangkutan. Kegiatan non-basis adalah kegiatan yang menyediakan barang dan jasa yang dibutuhkan oleh masyarakat yang berada di dalam batas wilayah perekonomian yang bersangkutan. Luas lingkup produksi dan pemasaranya adalah bersifat lokal. Aktivitas basis memiliki peranan sebagai penggerak utama dalam pertumbuhan suatu wilayah. Semakin besar ekspor suatu wilayah kewilayah lain akan semakin maju pertumbuhan wilayah tersebut, dan demikian sebaliknya. Setiap perubahan yang terjadi pada sektor basis akan menimbulkan multiplier effect dalam perekonomian regional (Adisasmita, 2005).

Analisis Location Quotient digunakan untuk menganalisis basis ekonomi suatu wilayah dan mengetahui seberapa besar tingkat spesialisasi sektorsektor basis atau unggulan (leading sectors). Analisis Location Quotient dapat menggunakan variabel tenaga kerja dan Produk Domestik Regional Bruto (PDRB) disuatu wilayah (Kabupaten) dibandingkan dengan rasio tenaga kerja dan sektor yang sama di provinsi dimana kabupaten tersebut dalam lingkupnya (Adisasmita, 2005).

Menurut Arsyad (2005), teori basis ekonomi ini merupakan faktor penentu utama pertumbuhan ekonomi suatu daerah karena berhubungan langsung dengan permintaan akan barang dan jasa dari luar daerah. Pertumbuhan industri-industri yang menggunakan sumber daya lokal, termasuk tenaga kerja dan bahan baku untuk diekspor, akan menghasilkan kekayaan daerah dan penciptaan peluang kerja (job creation).

Teori basis ekonomi didasarkan pemikiran bahwa suatu wilayah harus meningkatkan arus atau aliran langsung dari luar wilayah agar bisa tumbuh secara efektif, yaitu dengan cara meningkatkan ekspor. Nugroho \& Dahuri (2016) mengemukakan bahwa pasar ekspor merupakan penggerak utama atau sebagai mesin pertumbuhan ekonomi wilayah. Hasil ekspor mendatangkan pendapatan dan pendapatan tambahan melalui pengaruh pengganda (multiplier). Dengan demikian, kegiatan ekspor mengakibatkan pemasukan uang ke dalam wilayah dan dorongan untuk meningkatkan aktivitas perekonomian wilayah.

\section{Pergeseran Sektor Ekonomi}

Menurut Todaro \& Smith (2003), teori-teori perubahan struktural memusatkan perhatian pada transformasi struktur ekonomi dari pola pertanian ke struktur yang lebih modern serta memiliki sektor industri manufaktur dan sektor jasa-jasa yang tangguh. Aliran pendekatan struktural ini didukung oleh Lewis yang terkenal dengan model teoritisnya "surplus tenaga kerja dua sektor" dan Chenery yang sangat terkenal dengan analisis empirisnya tentang "pola-pola pembangunan" (patterns of depelovment).

Perekonomian suatu daerah dalam jangka panjang akan terjadi perubahan struktur perekonomian dimana semula mengandalkan sektor pertanian menuju sektor industri. Dari sisi tenaga kerja akan menyebabkan terjadinya perpindahan tenaga kerja dari sektor pertanian desa ke sektor industri kota, sehingga menyebabkan kontribusi pertanian menurun. Faktor penyebab terjadinya perubahan struktur perekonomian antara lain ketersediaan sumber daya alam, sumber daya manusia, sarana dan prasarana serta modal dan investasi yang masuk ke suatu daerah.

\section{Pengembangan Sektor Unggulan Sebagai Strategi Pembangunan Daerah}

Menurut (Arsyad, 2005), permasalahan pokok dalam pembangunan daerah adalah terletak pada penekanan kebijakan-kebijakan pembangunan yang didasarkan pada kekhasan daerah yang bersangkutan (endogenous depelovment) dengan menggunakan potensi sumberdaya manusia, kelembagaan, dan sumberdaya fisik secara lokal (daerah). Orientasi ini mengarahkan pada pengambilan inisiatif-inisiatif yang berasal dari daerah tersebut dalam proses pembangunan untuk menciptakan kesempatan kerja dan merangsang peningkatan ekonomi.

Pembangunan ekonomi dengan mengacu pada sektor dan komoditas unggulan selain berdampak pada percepatan pertumbuhan ekonomi juga akan berpengaruh pada perubahan mendasar dalam struktur ekonomi. Menurut Ratnasari (2014), sektor unggulan adalah sektor atau kegiatan ekonomi yang mempunyai potensi, kinerja dan prospek yang lebih baik dibandingkan dengan sektor lainnya sehingga diharapkan mampu menggerakkan kegiatan usaha ekonomi turunan lainnya, demi terciptanya kemandirian pembangunan wilayah. Sektor unggulan dapat pula diartikan sebagai sektor yang dapat menggerakkan pertumbuhan ekonomi wilayah sekitar yang ditunjukkan dengan parameter-parameter seperti 1) sumbangan sektor perekonomian terhadap perekonomian wilayah yang cukup tinggi, 2) sektor yang mempunyai multiplier effect yang tinggi, 3) sektor yang kandungan depositnya melimpah, dan 4) memiliki potensi added value yang cukup baik.

Penentuan sektor unggulan menjadi hal yang penting sebagai dasar perencanaan pembangunan daerah sesuai era otonomi daerah. Daerah memiliki 
kesempatan dan kewenangan untuk membuat kebijakan yang sesuai dengan potensi daerah demi mempercepat pembangunan ekonomi daerah untuk peningkatan kemakmuran masyarakat. Menurut Rachbini dalam Safwadi \& Rangkuti (2019) ada beberapa syarat agar suatu sektor tertentu menjadi sektor prioritas, yaitu sektor tersebut:

1. Harus menghasilkan produk yang mempunyai permintaan yang cukup besar, sehingga laju pertumbuhan berkembang cepat akibat dari efek permintaan.

2. Karena ada perubahan teknologi yang teradopsi secara kreatif, maka fungsi produksi baru bergeser dengan pengembangan kapasitas yang lebihluas.

3. Harus terjadi peningkatan investasi kembali dari hasil-hasil produksi sektor yang menjadi prioritas tersebut, baik swasta maupun pemerintah harus berkembang, sehingga mampu berpengaruh terhadap sektor lainnya.

4. Sektor tersebut harus berkembang, sehingga mampu memberi pengaruh terhadap sektor-sektor lainnya.

\section{METODE PENELITIAN}

Metode penelitian ini menggunakan mix method dengan pendekatan sequential explanatory design, yaitu diawali dengan pengumpulan dan analisis data kuantitatif kemudian diikuti dengan pendekatan kualitatif (Ivankova et al., 2006). Pendekatan kuantitatif deskriptif digunakan pada penelitian ini dengan tujuan untuk mengidentifikasi dan menganalisis sektor unggulandengan cara mengukur nilai PDRB sektoral tahun 2015-2019 berdasarkan Harga Konstan (ADHK) tahun 2010. Selanjutnya digunakan pendekatan kualitatif dengan teknik FGD, yaitu salah satu teknik pengumpulan data kualitatif yang didesain untuk memperoleh informasi keinginan, kebutuhan, sudut pandang, kepercayaan dan pengalaman peserta tentang suatu topik, dengan pengarahan dari seorang fasilitator atau moderator (Paramita \& Kristiana, 2013).

Hasil identifikasi dan analisis berupa penentuan sektor unggulan perekonomian di daerah, sehingga dapat menjadi bahan masukan atau saran dalam pengembangan potensi ekonomi regional Kabupaten Sumedang. Untuk menjawab permasalahan yang telah ditetapkan, maka digunakan beberapa metode analisis data yaitu analisis Location Quotient (LQ) digunakan untuk menentukan sektor basis dan non basis dalam perekonomian dan analisis Shift Share digunakan untuk mengetahui perubahan dan pergeseran sektor perekonomian wilayah.

Metode LQ merupakan salah satu pendekatan yang umum digunakan dalam model ekonomi basis sebagai langkah awal untuk memahami sektor kegiatan dari PDRB Kabupaten Sumedang yang menjadi pemacu pertumbuhan. Metode LQ digunakan untuk mengkaji kondisi perekonomian, mengarah pada identifikasi spesialisasi/basis kegiatan perekonomian (Kharisma \& Hadiyanto, 2019). Oleh karena itu, nilai LQ yang sering digunakan untuk penentuan sektor basis dapat dikatakan sebagai sektor yang akan mendorong tumbuhnya atau berkembangnya sektor lain serta berdampak pada penciptaan lapangan kerja. Untuk mendapatkan nilai LQ menggunakan metode yang mengacu pada formula yang dikemukakan oleh Bendavid-Valdalam Kuncoro (2004) sebagai berikut:

$\mathrm{LQ}=($ PDRBk.i : PDRBk) $:($ PDRBp.i $:$ PDRBp $) \rightarrow(1)$

Berdasarkan formulasi yang ditunjukkan dalam persamaan diatas, maka ada tiga kemungkinan nilai LQ yang dapat diperoleh yaitu:

1. Nilai $\mathrm{LQ}=1$. Ini berarti bahwa tingkat spesialisasi/basis sektor i di daerah Kabupaten Sumedang adalah sama dengan sektor yang sama dalam perekonomian Propinsi Jawa Barat.

2. Nilai LQ > $>$. Ini berarti bahwa tingkat spesialisasi/basis sektor i di daerah Kabupaten Sumedang lebih besar dibandingkan dengan sektor yang sama dalam perekonomian Propinsi Jawa Barat.

3. Nilai LQ < 1. Ini berarti bahwa tingkat spesialisasi/basis sektor i di daerah Kabupaten Sumedang lebih kecil dibandingkan dengan sektor yang sama dalam perekonomian Propinsi Jawa Barat.

Apabila nilai LQ > 1, maka dapat disimpulkan bahwa sektor tersebut merupakan sektor basis dan potensial untuk dikembangkan sebagai penggerak perekonomian Kabupaten Sumedang. Sebaliknya apabila nilai LQ $<1$, maka sektor tersebut bukan merupakan sektor basis dan kurang potensial untuk dikembangkan sebagai penggerak perekonomian Kabupaten Sumedang.

Analisis Shift Share digunakan untuk mengetahui perubahan dan pergeseran sektor pada perekonomian wilayah Kabupaten Sumedang. Hasil analisis Shift Share akan menggambarkan kinerja sektor-sektor dalam PDRB Kabupaten Sumedang dibandingkan Provinsi Jawa Barat. Kemudian dilakukan analisis terhadap penyimpangan yang terjadi sebagai hasil perbandingan tersebut. Bila penyimpangan tersebut positif, maka dikatakan suatu sektor dalam PDRB Kabupaten Sumedang memiliki keunggulan kompetitif atau sebaliknya. Teknik analisis Shift Share menurut Arsyad (2005), membagi perubahan pertumbuhan (Dij) menjadi tiga komponen, yaitu:

1. Pengaruh pertumbuhan ekonomi di atasnya $\left(\mathrm{Nij}_{\mathrm{ij}}\right)$, yang diukur dengan cara menganalisis perubahan pergeseranagregat secara sektoral dibandingkan dengan perubahan pada sektor yang sama di perekonomian yang dijadikan acuan. 
2. Pengaruh pergeseran proporsional atau bauran industri $\left(\mathrm{M}_{\mathrm{ij}}\right)$, yang mengukur perubahan pertumbuhan atau penurunan pada daerah studi dibandingkan dengan perekonomian yang lebih besar yang dijadikan acuan. Dimana melaui pengukuran ini dimungkinkan untuk mengetahui apakah perekonomian daerah studi terkonsentrasi pada industri-industri yang tumbuh lebih cepat ketimbang perekonomian yang dijadikan acuan.

3. Pengaruh pergeseran diferensial atau keunggulan kompetitif (Cij), yang menentukan seberapa jauh daya saing industri daerah (lokal) dengan perekonomian yang dijadikan acuan, dimana jika pergeseran diferensial dari suatu sektor adalah positif, maka sektor tersebut lebih tinggi daya saingnya ketimbang sektor yang sama pada perekonomian yang dijadikan acuan.

Setelah data diolah secara kuantitatif, langkah berikutnya adalah pemaparan dan membahas hasil pengolahan data tersebut bersama para stakeholder pembangunan ekonomi di Kabupaten Sumedang untuk memberikan argumentasi mengenai sektor unggulan yang potensial untuk dikembangkan atau menjadi prioritas pembangunan di Kabupaten Sumedang, melalui teknik FGD.

\section{ANALISIS DAN PEMBAHASAN}

\section{Analisis Location Quotient (LQ)}

Ukuran konsentrasi dari aktivitas perekonomian sektoral menjadi bagian penting dalam analisis ekonomi makro sektoral di tingkat daerah. Besaran konsentrasi diukur berdasarkan nilai relatif dari nilai tambah masing-masing sektor perekonomian di suatu daerah terhadap nilai tambah sektoral di wilayah referensinya, dalam hal ini wilayah Provinsi Jawa Barat dijadikan sebagai wilayah referensi Kabupaten Sumedang. Sebelum melakukan analisis LQ, terlebih dahulu dilakukan pengumpulan data Produk Domestik Regional Bruto (PDRB) Kabupaten Sumedang dan Provinsi Jawa Barat berdasarkan tahun dasar 2010 untuk periode 2015 - 2019 (Tabel 1).

Tabel 1.Perkembangan PDRB Provinsi Jawa Barat dan Kabupaten Sumedang 2015-2019

\begin{tabular}{|c|c|c|c|c|c|c|c|c|c|c|c|}
\hline \multirow{3}{*}{ No } & \multirow{3}{*}{ Lapangan Usaha } & \multicolumn{10}{|c|}{ PDRB ADHK (Milyar Rupiah) } \\
\hline & & \multicolumn{5}{|c|}{ Kabupaten Sumedang } & \multicolumn{5}{|c|}{ Provinsi Jawa Barat } \\
\hline & & 2015 & 2016 & 2017 & 2018 & 2019 & 2015 & 2016 & 2017 & 2018 & 2019 \\
\hline 1 & $\begin{array}{l}\text { Pertanian, } \\
\text { Kehutanan, dan } \\
\text { Perikanan }\end{array}$ & 3,490 & 3,616 & 3,862 & 3,915 & 3,988 & 92,803 & 98,097 & 99,669 & 101,777 & 104,657 \\
\hline 2 & $\begin{array}{l}\text { Pertambangan dan } \\
\text { Penggalian }\end{array}$ & 19 & 19 & 19 & 20 & 20 & 27,404 & 27,139 & 26,590 & 25,496 & 24,791 \\
\hline 3 & Industri Pengolahan & 3,430 & 3,643 & 3,835 & 4,244 & 4,759 & 524,467 & 549,471 & 578,858 & 616,442 & 641,352 \\
\hline 4 & $\begin{array}{l}\text { Pengadaan Listrik } \\
\text { dan Gas }\end{array}$ & 80 & 85 & 94 & 96 & 101 & 5,940 & 6,140 & 5,438 & 5,439 & 5,374 \\
\hline 5 & $\begin{array}{l}\text { Pengadaan Air, } \\
\text { Pengelolaan } \\
\text { Sampah, Limbah } \\
\text { dan Daur Ulang }\end{array}$ & 5 & 6 & 6 & 6 & 6 & 949 & 1,009 & 1,081 & 1,135 & 1,169 \\
\hline 6 & Konstruksi & 1,985 & 2,112 & 2,277 & 2,469 & 2,600 & 98,555 & 103,507 & 111,001 & 119,305 & 126,631 \\
\hline 7 & $\begin{array}{l}\text { Perdagangan Besar } \\
\text { dan Eceran; } \\
\text { Reparasi Mobil dan } \\
\text { Sepeda Motor }\end{array}$ & 3,419 & 3,563 & 3,740 & 3,897 & 4,111 & 190,440 & 198,865 & 207,910 & 216,614 & 232,876 \\
\hline 8 & $\begin{array}{l}\text { Transportasi dan } \\
\text { Pergudangan }\end{array}$ & 900 & 953 & 1,007 & 1,056 & 1,106 & 56,171 & 61,297 & 64,259 & 67,702 & 71,064 \\
\hline 9 & $\begin{array}{l}\text { Penyediaan } \\
\text { Akomodasi dan } \\
\text { Makan Minum }\end{array}$ & 834 & 896 & 951 & 1,020 & 1,081 & 29,777 & 32,559 & 35,285 & 38,160 & 40,928 \\
\hline 10 & $\begin{array}{l}\text { Informasi dan } \\
\text { Komunikasi }\end{array}$ & 766 & 873 & 962 & 1,061 & 1,160 & 41,879 & 47,857 & 53,527 & 58,421 & 63,861 \\
\hline 11 & $\begin{array}{l}\text { Jasa Keuangan dan } \\
\text { Asuransi }\end{array}$ & 744 & 813 & 868 & 905 & 966 & 29,522 & 33,031 & 34,180 & 35,727 & 36,521 \\
\hline 12 & Real Estat & 347 & 364 & 400 & 436 & 472 & 13,838 & 14,738 & 16,110 & 17,663 & 19,349 \\
\hline
\end{tabular}




\begin{tabular}{|c|c|c|c|c|c|c|c|c|c|c|c|}
\hline \multirow{3}{*}{ No } & \multirow{3}{*}{ Lapangan Usaha } & \multicolumn{10}{|c|}{ PDRB ADHK (Milyar Rupiah) } \\
\hline & & \multicolumn{5}{|c|}{ Kabupaten Sumedang } & \multicolumn{5}{|c|}{ Provinsi Jawa Barat } \\
\hline & & 2015 & 2016 & 2017 & 2018 & 2019 & 2015 & 2016 & 2017 & 2018 & 2019 \\
\hline 13 & Jasa Perusahaan & 15 & 16 & 17 & 19 & 20 & 4,933 & 5,335 & 5,784 & 6,284 & 6,861 \\
\hline 14 & $\begin{array}{l}\text { Administrasi } \\
\text { Pemerintahan, } \\
\text { Pertahanan dan } \\
\text { Jaminan Sosial } \\
\text { Wajib }\end{array}$ & 1,126 & 1,158 & 1,168 & 1,183 & 1,223 & 24,987 & 25,739 & 26,933 & 27,361 & 28,755 \\
\hline 15 & Jasa Pendidikan & 1,197 & 1,279 & 1,384 & 1,459 & 1,549 & 32,419 & 34,886 & 37,910 & 40,075 & 42,156 \\
\hline 16 & $\begin{array}{l}\text { Jasa Kesehatan dan } \\
\text { Kegiatan Sosial }\end{array}$ & 233 & 251 & 273 & 293 & 313 & 8,881 & 9,723 & 10,538 & 11,370 & 12,448 \\
\hline \multirow[t]{2}{*}{17} & Jasa lainnya & 360 & 382 & 414 & 439 & 464 & 24,121 & 26,227 & 28,791 & 30,718 & 32,912 \\
\hline & PDRB & 18,950 & 20,030 & 21,277 & 22,517 & 23,939 & $1,207,083$ & $1,275,619$ & $1,343,864$ & $1,419,689$ & $1,491,706$ \\
\hline
\end{tabular}

Sumber: BPS berbagai edisi

Selanjutnya data diolah hingga diperoleh nilai LQ di setiap tahun dari 2015 hingga 2019 dan diperoleh nilai rata-rata sehingga setiap sektor atau lapangan usaha dapat dikelompokkan sebagai sektor basis atau non basis (Tabel 2). Sektor yang terkategori basis berarti memiliki konsentrasi yang lebih tinggi dibanding sektor yang sama di Jawa Barat.

Tabel 2. Sektor-Sektor Basis Perekonomian Kabupaten Sumedang 2015-2019

\begin{tabular}{|c|c|c|c|c|c|c|c|c|}
\hline No & Lapangan Usaha & 2015 & 2016 & 2017 & 2018 & 2019 & Rerata & Keterangan \\
\hline 1 & Pertanian, Kehutanan, dan Perikanan & 2.40 & 2.35 & 2.45 & 2.43 & 2.37 & 2.40 & Basis \\
\hline 2 & Pertambangan dan Penggalian & 0.04 & 0.05 & 0.05 & 0.05 & 0.05 & 0.05 & Non Basis \\
\hline 3 & Industri Pengolahan & 0.42 & 0.42 & 0.42 & 0.43 & 0.46 & 0.43 & Non Basis \\
\hline 4 & Pengadaan Listrik dan Gas & 0.85 & 0.88 & 1.09 & 1.12 & 1.17 & 1.02 & Basis \\
\hline 5 & $\begin{array}{l}\text { Pengadaen Air, Pengelolaen Sampah, Limbah } \\
\text { dan Daur Ulang }\end{array}$ & 0.35 & 0.35 & 0.33 & 0.31 & 0.31 & 0.33 & Non Basis \\
\hline 6 & Konstruksi & 1.28 & 1.30 & 1.30 & 1.30 & 1.28 & 1.29 & Basis \\
\hline 7 & $\begin{array}{l}\text { Perdagangan Beaar dan Eceran; Reparasi } \\
\text { Mobil dan Sepeda Motor }\end{array}$ & 1.14 & 1.14 & 1.14 & 1.13 & 1.10 & 1.13 & Вasis \\
\hline 8 & Transportasi dan Pergudangan & 1.02 & 0.99 & 0.99 & 0.98 & 0.97 & 0.99 & Non Basis \\
\hline 9 & Penyedian Alkomodasi dan Makan Minum & 1.78 & 1.75 & 1.70 & 1.69 & 1.65 & 1.71 & Basis \\
\hline 10 & Informasi dan Komunikasi & 1.16 & 1.16 & 1.13 & 1.15 & 1.13 & 1.15 & Basis \\
\hline 11 & Jasa Keuangan dan Asuransi & 1.61 & 1.57 & 1.60 & 1.60 & 1.65 & 1.60 & Basis \\
\hline 12 & Real Estat & 1.60 & 1.57 & 1.57 & 1.56 & 1.52 & 1.56 & Basis \\
\hline 13 & Jasa Perusahaen & 0.19 & 0.19 & 0.19 & 0.19 & 0.18 & 0.19 & Non Basis \\
\hline 14 & $\begin{array}{l}\text { Administrasi Pemerintahan, Pertahanan dan } \\
\text { Jaminan Sosial Wajib }\end{array}$ & 2.87 & 2.87 & 2.74 & 2.73 & 2.65 & 2.77 & Basis \\
\hline 15 & Jasa Pendidikan & 2.35 & 2.34 & 2.31 & 2.29 & 2.29 & 2.32 & Basis \\
\hline 16 & Jasa Kesehatan dan Kegiatan Sosial & 1.67 & 1.64 & 1.64 & 1.62 & 1.57 & 1.63 & Basis \\
\hline 17 & Jasa lainnya & 0.95 & 0.93 & 0.91 & 0.90 & 0.88 & 0.91 & Non Basis \\
\hline
\end{tabular}

Sumber: Hasil Perhitungan 
Berdasarkan hasil perhitungan nilai konsentrasi sektoral perekonomian makro Kabupaten Sumedang periode 2015 - 2019, diperoleh hasil bahwa dari 17 sektor (lapangan usaha) yang ada dalam perekonomian daerah Kabupaten Sumedang, terdapat 11 sektor yang bisa terkategorikan sebagai sektor basis atau yang memiliki konsentrasi lebih besar dibandingkan dengan sektor yang sama di Provinsi Jawa Barat. Sektor tersebut berdasarkan kelompoknya adalah:

1. Sektor Primer: Sektor Pertanian, Kehutanan, dan Perikanan;

2. Sektor sekunder: Sektor Pengadaan Listrik dan Gas; Sektor Konstruksi; Sektor Perdagangan; Sektor Penyedia Akomodasi dan Makan Minum; Sektor Informasi dan Komunikasi; Sektor Jasa Keuangan; dan Sektor Real Estate;

3. Sektor Tersier: Sektor Administrasi Pemerintahan; Sektor Pendidikan; dan Sektor Kesehatan.

Berdasarkan hasil perhitungan indek konsentrasi tersebut, dapat diambil kesimpulan bahwa seharusnya kebijakan pembangunan ekonomi makro sektoral di Kabupaten Sumedang difokuskan untuk meningkatkan volume dari aktivitas sektor-sektor yang memiliki konsentrasi yang tinggi tersebut.

Apabila fokus pembangunan di lakukan di sektorsektor lain, maka potensi pendapatan yang berasal dari luar Kabupaten Sumedang akan berkurang yang berakibat laju pertumbuhahn perekonomian akan melambat (Bappeda Kab. Sumedang, 2016).

Dari tabel tersebut terlihat bahwa jumlah sektor/lapangan usaha yang menjadi tumpuan pendapatan perekonomian Kabupaten Sumedang (terkategorikan sebagai sektor basis) lebih banyak dibandingkan dengan lapangan usaha yang terkategorikan sebagai sektor non basis. Dengan demikian dapat dikatakan bahwa pada dasarnya Kabupaten Sumedang memiliki keragaman sektor yang cukup besar untuk bisa menopang perkembangan perekonomiannya.

Namun demikian, banyaknya lapangan usaha yang terkategori sektor basis belum sejalan dengan cepatnya pertumbuhan ekonomi Kabupaten Sumedang, sehingga perlu dipetakan sektor basis mana saja yang mampu tumbuh di atas atau di bawah pertumbuhan ekonomi Kabupaten Sumedang. Beberapa gambar berikut merupakan tipologi dari sektor perekonomian di Kabupaten Sumedang selama 2015 - 2019.

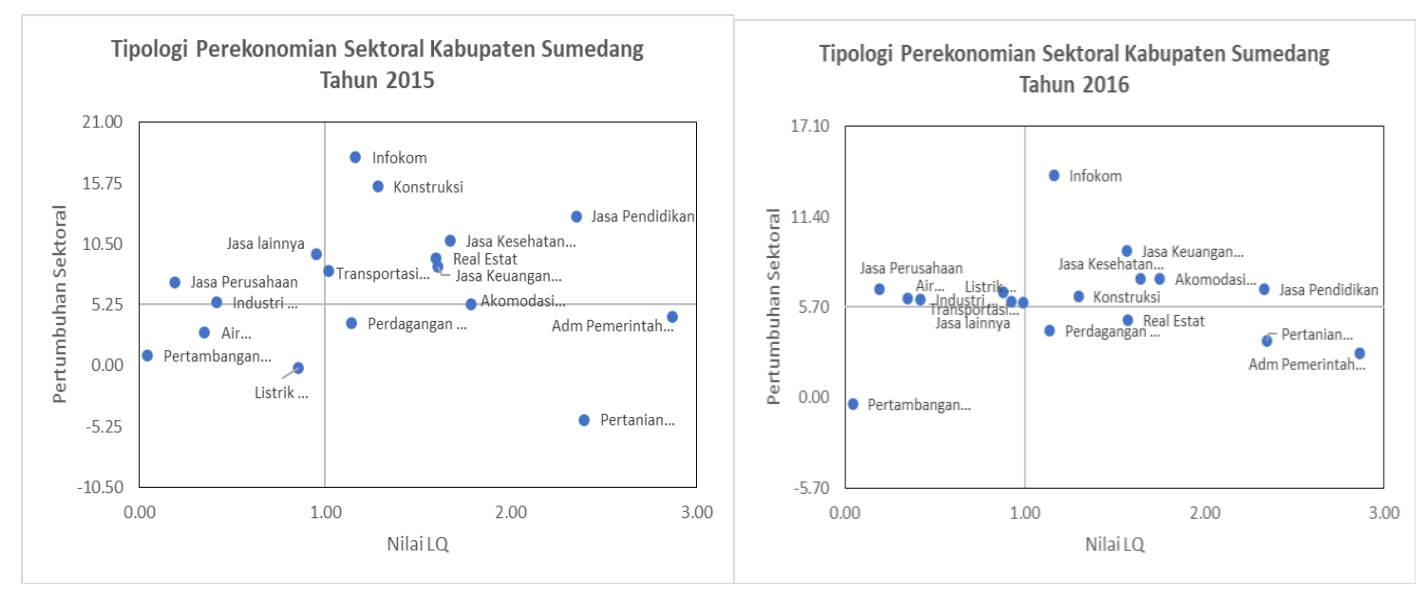




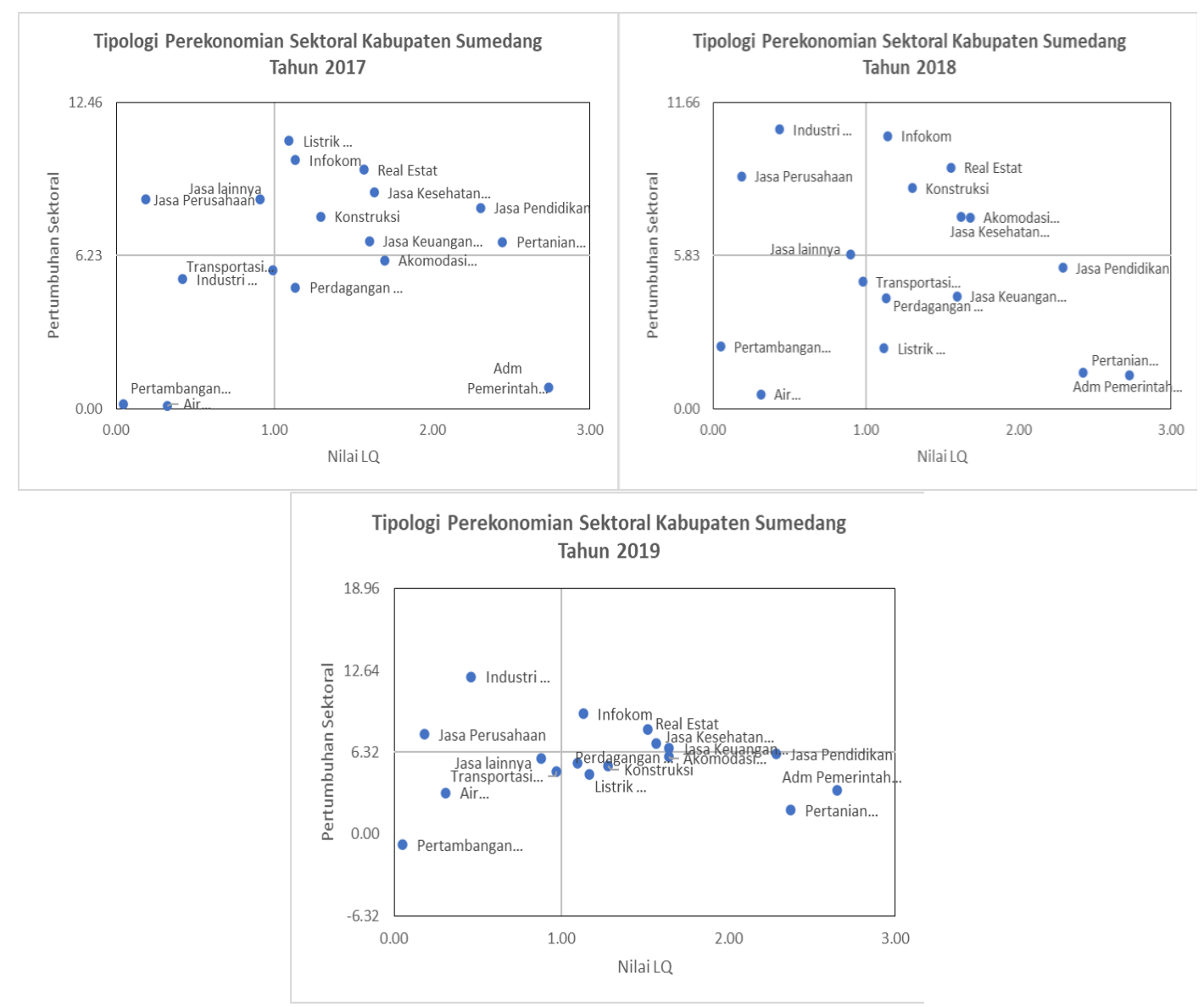

Gambar 3. Tipologi Perekonomian Sektoral Kabupaten Sumedang Tahun 2015 - 2019

Berdasarkan tipologi di atas, terdapat sektor basis yang secara konsisten selama 2015 - 2019 selalu tumbuh lebih cepat dari pertumbuhan ekonomi Kabupaten Sumedang, yaitu sektor informasi dan komunikasi dan sektor jasa kesehatan. Selain itu, pilihan prioritas pengembangan dapat mempertimbangkan sektor basis yang memberikan share cukup besar dalam perekonomian daerah seperti sektor pertanian, kehutanan, dan perikanan namun secara rata-rata masih tumbuh di bawah pertumbuhan ekonomi Kabupaten Sumedang. Diperlukan usaha agar sektor pertanian, kehutanan, dan perikanan dapat tumbuh lebih cepat sehingga akan memberikan daya ungkit tinggi pada perekonomian Kabupaten Sumedang.

\section{Analisis Shift Share}

Analisis shift-share (SS) berusaha menjelaskan lebih detail mengenai sumber pertumbuhan (perubahan pada nilai tambah) yang ada di masing-masing sektor selama periode 2015 hingga tahun 2019 sehingga dapat diketahui dari mana saja sumber pertumbuhan tersebut diperoleh. Hasil perhitungan metode ShiftShare yang didapat dari perekonomian sektoral Kabupaten Sumedang selama periode 2015 hingga 2019 ditunjukkan seperti pada Tabel di bawah ini. Berdasarkan tabel tersebut terlihat bahwa ada beberapa sektor yang memiliki bauran lapangan usaha yang cukup baik (ditunjukkan oleh nilai Mij bernilai positif pada Tabel 3.), diantaranya adalah:

- Sektor Konstruksi

- Sektor Transportasi dan Pergudangan

- Sektor Penyediaan Akomodasi dan Makan Minum

- Sektor Informasi dan Komunikasi

- Sektor Jasa Keuangan dan Asuransi

- Sektor Real Estat

- Sektor Jasa Perusahaan

- Sektor Pendidikan

- Sektor Jasa Kesehatan dan Kegiatan Sosial

- Sektor Jasa lainnya

Informasi dan pengertian yang bisa didapat dari besaran bauran lapangan usaha yang positif tersebut adalah bahwa ke 10 sektor tersebut memiliki pertumbuhan ekonomi yang lebih besar dibandingkan dengan pertumbuhan ekonomi total di Provinsi Jawa Barat, sehingga diharapkan ada peningkatan pada nilai tambah yang terjadi di Kabupaten Sumedang sebesar angka yang tertera pada kolom Mij di Tabel 3. Akan tetapi hal yang sebaliknya akan terjadi pada sektor-sektor yang memiliki bauran lapangan usaha (Mij) yang bernilai negatif. 
40 Coopetition, Vol XII, Nomor 1, Maret 2021, 31 - 44

(E-ISSN : 2615-4978, P-ISSN : 2086-4620)

Tabel 2. Hasil Perhitungan Shift Share Perekonomian Sektoral Kab. Sumedang, 2015 - 2019

\begin{tabular}{rlrrrr}
\hline No & \multicolumn{1}{c}{ Lapangan Usaha } & Nij & \multicolumn{1}{c}{ Mij } & \multicolumn{1}{c}{ Cij } & \multicolumn{1}{c}{ Dij } \\
\hline 1 & Pertanian, Kehutanan, dan Perikanan & 823.03 & -377.18 & 51.70 & 497.55 \\
\hline 2 & Pertambangan dan Penggalian & 4.55 & -6.38 & 2.09 & 0.26 \\
\hline 3 & Industri Pengolahan & 808.71 & -44.34 & 565.05 & 1329.42 \\
\hline 4 & Pengadaan Listrik dan Gas & 18.78 & -26.37 & 28.78 & 21.19 \\
\hline 5 & $\begin{array}{l}\text { Pengadaan Air, Pengelolaan Sampah, Limbah dan } \\
\text { Daur Ulang }\end{array}$ & 1.24 & -0.02 & -0.67 & 0.54 \\
\hline 6 & Konstruksi & 468.06 & 97.43 & 49.26 & 614.75 \\
\hline 7 & $\begin{array}{l}\text { Perdagangan Besar dan Eceran; Reparasi Mobil } \\
\text { dan Sepeda Motor }\end{array}$ & 806.12 & -44.31 & -69.56 & 692.25 \\
\hline 8 & Transportasi dan Pergudangan & 212.11 & 26.40 & -31.65 & 206.86 \\
\hline 9 & Penyediaan Akomodasi dan Makan Minum & 196.63 & 115.68 & -64.92 & 247.39 \\
\hline 10 & Informasi dan Komunikasi & 180.59 & 221.43 & -7.57 & 394.46 \\
\hline 11 & Jasa Keuangan dan Asuransi & 175.41 & 0.96 & 45.29 & 221.66 \\
\hline 12 & Real Estat & 81.87 & 56.41 & -13.77 & 124.52 \\
\hline 13 & Jasa Perusahaan & 3.51 & 2.31 & -0.47 & 5.35 \\
\hline 14 & $\begin{array}{l}\text { Administrasi Pemerintahan, Pertahanan dan } \\
\text { Jaminan Sosial Wajib }\end{array}$ & 265.54 & -95.75 & -73.03 & 96.75 \\
\hline 15 & Jasa Pendidikan & 282.33 & 77.31 & -8.07 & 351.57 \\
\hline 16 & Jasa Kesehatan dan Kegiatan Sosial & 55.01 & 38.70 & -13.76 & 79.96 \\
\hline 17 & Jasa lainnya & 84.88 & 46.32 & -26.75 & 104.46 \\
\hline Sw & & &
\end{tabular}

Sumber: Hasil Perhitungan

Meskipun berdasarkan hasil perhitungan bauran industri (Mij) terlihat bahwa potensi pertumbuhan ekonomi sektoral di Kabupaten Sumedang relatif tersebar di banyak sektor, akan tetapi jika dilihat dari sisi daya saingnya (nilai $\mathrm{Cij}$ ), maka hanya ada beberapa sektor perekonomian di Kabupaten Sumedang yang memiliki daya saing sektoral yang cukup baik (dalam pengertian laju pertumbuhan sektoralnya lebih besar dibandingkan dengan laju pertumbuhan sektoral di Jawa Barat). Adapun sektorsektor yang memiliki daya saing di Kabupaten Sumedang diantaranya adalah:

- Sektor Pertanian, Kehutanan, dan Perikanan

- Sektor Pertambangan dan Penggalian

- Sektor Industri Pengolahan

- Sektor Pengadaan Listrik dan Gas

- Sektor Konstruksi

- Sektor Jasa Keuangan dan Asuransi

Sektor primer, khususnya pertanian di Kabupaten Sumedang sebenarnya merupakan sektor yang memiliki daya saing yang cukup besar di tingkat Provinsi Jawa Barat. Potensi pertanian ini perlu disertai dengan peningkatan produktivitas yang lebih baik lagi. Demikian juga dengan sektor sekunder, khususnya industri pengolahan juga memiliki potensi besar di tingkat Provinsi Jawa Barat. Keberadaan WadukJatigede dapat menjadi potensi peningkatan perekonomian di sektor listrik. Daya listrik yang mampu diciptakan oleh Waduk Jatigede diharapkan mampu memberikan multiplier effect bagi perkembangan perekonomian makro daerah dimasa yang akan datang (Bappeda Kab. Sumedang, 2016). Sektor konstruksi juga telah berkembang sedemikian rupa terutama sejak pembangunan dua megaproyek nasional waduk Jatigede dan jalan tol Cisumdawu sehingga sektor konstruksi di Sumedang mampu bersaing dengan daerah-daerah lain di Jawa Barat. Sedangkan untuk sektor sektortertier, ternyata hanya jasa keuangan dan asuransi yang memiliki daya saing di tingkat Jawa Barat seiring dengan berkembangnya asuransi dan kredit mikro selama kurun waktu 20152019.

Hasil analisis Shift Share adalah sebuah kebijakan terkait dengan pengembangan sektor-sektor perekonomian di suatu daerah. Berdasarkan analisis ini sektor-sektor yang perlu dikembangakan di Kabupaten Sumedang adalah sektor-sektor dengan karakteristik memiliki daya saing yang tinggi serta sektor-sektor yang memiliki bauran lapangan usaha yang positif. Oleh karenanya maka penentuan sektor- 
sektor yang menjadi prioritas pembangunan sektoral di Kabupaten Sumedang dilakukan dengan cara melakukan overlay terhadap kedua komponen tersebut (Mij dan Cij). Berdasarkan analisis overlay maka diperoleh 2 sektor yang menjadi prioritas pembangunan sektoral Kabupaten Sumedang (dilihat dari performancenya selama periode 2015 - 2019), yaitu sektor konstruksi dan sektor jasa keuangan dan asuransi.

Sektor konstruksi, termasuk didalamnya adalah pembangunan infrastruktur yang menjadi salah satu pendorong pertumbuhan. Ketersediaan infrastruktur, khususnya infrastruktur jalan, akan membuat biaya produksi menjadi lebih murah, sehingga produksi barang dan jasa menjadi lebih efisien. Selain itu ketersediaan infrastruktur juga akan mendorong terciptanya konektivitas yang lebih baik, sehingga potensi seluruh daerah yang ada di Kabupaten Sumedang bisa termanfaatkan lebih baik lagi. Fokus pembangunan infrastruktur yang dilakukan dalam perencanaan pembangunan selama ini perlu diarahkan pada sektor yang memiliki daya ungkit perekonomian seperti infrastruktur jalan ke tempat wisata dan irigasi pertanian, dan pada pemenuhan kebutuhan dasar masyarakat seperti penyediaan sarana air bersih, serta perbaikan kualitas lingkungan seperti infrastruktur pengelolaan sampah/limbah. Dalam pembangunan jangka Panjang, ketersediaan infrastruktur publik yang lebih baik akan mendorong pertumbuhan yang lebih tinggi, seperti yang dijelaskan oleh teori Infrastructure Led Growth yang kini berkembang menjadi Infrastructure Led Development (Agénor, 2010).

Sektor Jasa Keuangan dan Asuransi di Kabupaten Sumedang selama 2015 - 2019 mampu mendorong aktivitas perekonomian masyarakat, terutama bagi para pelaku Usaha Mikro dan Kecil (UMK). Berkembangnya sektor jasa keuangan dan asuransi ini turut mengatasi kebutuhan permodalan dan akses ke lembaga keuangan dalam kegiatan ekonomi masyarakat Sumedang, diantaranya adanya program Kredit Senyum Manis bagi usaha mikro yang digulirkan Pemkab Sumedang melalui Bank Sumedang dan Dinas Koperasi. Berdasarkan penelitian Risnawati (2018) bahwa permasalahan yang dihadapi UKM di Sumedang tidak lagi menempatkan masalah permodalan dan akses ke lembaga keuangan sebagai masalah utama, namun beralih pada perijinan, manajemen keuangan, dan manajemen pemasaran.

Sektor atau lapangan usaha unggulan akan semakin spesifik dengan melakukan overlay LQ dan Shift Share seperti terlihat pada Tabel 4. Sektor yang terkategori basis, tumbuh lebih cepat dan berdaya saing dibandingkan sektor yang sama di tingkat Provinsi Jawa Barat adalah sektor konstruksi dan sektor jasa keuangan dan asuransi. Adapun dari 3 sektor utama di Sumedang, sektor pertanian, kehutanan, dan perikanan memiliki potensi yang lebih unggul dibandingkan sektor industri pengolahan dan sektor perdagangan, yaitu selain basis juga memiliki daya saing.

Tabel 3. Overlay LQ dan Shift Share Kab. Sumedang Tahun 2015 - 2019

\begin{tabular}{|c|c|c|c|c|}
\hline No & Lapangan Usaha & LQ & Mij & $\mathbf{C i j}$ \\
\hline 1 & Pertanian, Kehutanan, dan Perikanan & Basis & Lambat & Kompetitif \\
\hline 2 & Pertambangan dan Penggalian & Non Basis & Lambat & Kompetitif \\
\hline 3 & Industri Pengolahan & Non Basis & Lambat & Kompetitif \\
\hline 4 & Pengadaan Listrik dan Gas & Basis & Lambat & Kompetitif \\
\hline 5 & Pengadaan Air, Pengelolaan Sampah, Limbah dan Daur Ulang & Non Basis & Lambat & Tidak kompetitif \\
\hline 6 & Konstruksi & Basis & Cepat & Kompetitif \\
\hline$\overline{7}$ & Perdagangan Besar dan Eceran; Reparasi Mobil dan Sepeda Motor & Basis & Lambat & Tidak kompetitif \\
\hline 8 & Transportasi dan Pergudangan & Non Basis & Cepat & Tidak kompetitif \\
\hline 9 & Penyediaan Akomodasi dan Makan Minum & Basis & Cepat & Tidak kompetitif \\
\hline 10 & Informasi dan Komunikasi & Basis & Cepat & Tidak kompetitif \\
\hline 11 & Jasa Keuangan dan Asuransi & Basis & Cepat & Kompetitif \\
\hline 12 & Real Estat & Basis & Cepat & Tidak kompetitif \\
\hline 13 & Jasa Perusahaan & Non Basis & Cepat & Tidak kompetitif \\
\hline 14 & Administrasi Pemerintahan, Pertahanan dan Jaminan Sosial Wajib & Basis & Lambat & Tidak kompetitif \\
\hline$\overline{15}$ & Jasa Pendidikan & Basis & Cepat & Tidak kompetitif \\
\hline$\overline{16}$ & Jasa Kesehatan dan Kegiatan Sosial & Basis & Cepat & Tidak kompetitif \\
\hline 17 & Jasa lainnya & Non Basis & Cepat & Tidak kompetitif \\
\hline
\end{tabular}

Sumber: Hasil Perhitungan 


\section{Hasil Pembahasan Focus Group Discussion}

Setelah diketahui pemetaan sektor atau lapangan usaha berdasarkan alat analisis kuantitatif (LQ dan Shift Share) maka hasilnya dibahas dengan stakeholder pembangunan ekonomi di Kabupaten Sumedang, antara lain melibatkan unsur Pemerintah Kabupaten Sumedang dari berbagai instansi terkait seperti Dinas Pertanian, Dinas Koperasi, Perindustrian dan Perdagangan, Bagian Ekonomi Sekretariat Daerah, Dinas Peternakan dan Perikanan, dan BPS Kabupaten Sumedang sebagai penyedia data penelitian. Selain itu dihadiri pula oleh stakeholder dari kalangan akademisi seperti dari STIE dan STMIK Sebelas April Sumedang, serta Tim Akselerasi Pembangunan Kabupaten Sumedang.

Hasil FGD mengaitkan antara analisis sektor unggulan dengan kondisi pandemi Covid-19 yang saat ini mempengaruhi pertumbuhan sektor atau lapangan usaha di semua daerah, khususnya Kabupaten Sumedang. Banyak lapangan usaha yang terkontraksi akibat adanya pembatasan sosial, khususnya di sektor transportasi dan pergudangan, sektor industri pengolahan, dan sektor perdagangan. Sementara ada pula beberapa sektor yang justru tumbuh signifikan seperti sektor informasi dan komunikasi dan sektor jasa kesehatan. Ada satu sektor penting yang menjadi salah satu kontributor utama perekonomian Kabupaten Sumedang yang tidak mengalami kontraksi bahkan masih tumbuh positif, yaitu sektor pertanian, kehutanan, dan perikanan. Oleh karena itu pilihan audiens FGD menempatkan sektor pertanian, kehutanan, dan perikanan sebagai sektor potensial berdasarkan beberapa keunggulan sebagai berikut:

1. Sektor yang terkategori rendah risiko dari dampak pandemi covid-19 baik dari aspek social distancing maupun kelangsungan aktivitas lainnya. Berbeda dengan aktivitas di perkantoran, pabrik atau tempat-tempat kerja di ruang tertutup dan padat pekerja.

2. Penopang ketahanan pangan, khususnya di era pandemi agar tidak menjadi krisis pangan yang bisa memicugejolak sosial di tengah masyarakat.

3. Jaring pengaman sosial (social safety net) alamiah melalui serapan tenaga kerja terbesar.

4. Mempertahankan aktivitas ekonomi di pedesaan sehingga peningkatan angka kemiskinan tahun 2020 dapat lebih diredam.

Sektor lain yang memiliki keunggulan hasil overlay LQ dan Shift Share yaitu sektor konstruksi dan sektor jasa keuangan dan asuransi perlu tetap didorong untuk mempercepat pemulihan ekonomi karena kemampuannya tumbuh lebih cepat dan memiliki daya saing. Sektor konstruksi diperlukan untuk mendukung infrastruktur terutama untuk irigasi pertanian dan transportasi sehingga konektivitas antar wilayah menjadi lebih baik dan mampu mendorong aktivitas perekonomian masyarakat, sementara sektor jasa keuangan dan asuransi dapat mendukung pembiayaan usaha mikro kecil yang terpukul akibat pandemi.

Sektor lain yang perlu menjadi perhatian Pemerintah Kabupaten Sumedang adalah sektor informasi dan komunikasi yang menjadi basis dan tumbuh sangat konsisten selama 5 tahun terakhir bahkan diperkirakan akan semakin tinggi pertumbuhannya di tahun 2020 ini karena intensitas pemanfaatan internet dalam membantu pekerjaan dan pembelajaran. Digitalisasipada berbagai lapangan usaha, terutama pada sektor utama penggerak perekonomian seperti pertanian dan perdagangan menjadi tantanganagar dapat bertahan dan bersaing di pasar yang semakin terbuka. Sektor jasa kesehatan yang juga mampu tumbuh konsisten dan menjadi basis selama 5 tahun terakhir menjadi sangat strategis mengingat pentingnya pelayanan kesehatan masyarakat terutama di masa pandemi Covid-19.

\section{SIMPULAN DAN SARAN}

\section{Simpulan}

Kabupaten Sumedang selama periode 2015 - 2019, memiliki 11 dari 17 sektor/lapangan usaha yang merupakan sektor basis (memiliki konsentrasi lebih besar dibandingkan dengan sektor yang sama di Provinsi Jawa Barat). Namun, hanya 2 sektor saja yang secara konsisten mampu tumbuh di atas pertumbuhan ekonomi Kabupaten Sumedang, yaitu sektor Informasi dan Komunikasi dan sektor Jasa Kesehatan. Sementara berdasarkan analisis Shift Share, juga terdapat 2 sektor yang mampu tumbuh lebih cepat dari sektor yang sama di Provinsi Jawa Barat dan memiliki daya saing, yaitu sektor konstruksi dan sektor jasa keuangan dan asuransi. Sementara sektor Pertanian, Kehutanan, dan Perikanan punya peran strategis mengingat besarnya share sektor basis dan memiliki daya saing dibandingkan daerah acuan (Provinsi Jawa Barat), hanya saja diperlukan upaya mendorong produktivitas sektor ini agar mampu tumbuh lebih cepat.

\section{Saran}

Keterbatasan penelitian ini terdapat pada kedalaman data yang diperoleh dari BPS Kabupaten Sumedang yang hanya pada level sektor atau lapangan usaha. Sementara harapan yang lebih besar untuk sampai pada analisis level sub sektor bahkan komoditas belum bisa dicapai dalam penelitian ini. Misalnya ketika diketahui bahwa sektor pertanian, kehutanan, dan perikanan merupakan sektor basis maka informasi lanjutan mengenai sub sektor bahkan komoditasapa yang merupakan basis tersebut belum bisa diperoleh. Hal ini sekaligus menjadi masukan untuk penelitian berikutnya dengan memperdalamanalsisi pada level 
sub sektor dan komoditas, khususnya pada sektorsektor yang terkategori basis, memiliki spesialisasi dan kompetitif sehingga akan memudahkan pengambil kebijakan dalam merencanakan pembangunan sektoral di Kabupaten Sumedang.

\section{DAFTAR PUSTAKA}

Adhitama, R. (2012). Pengembangan sektor-sektor ekonomi di tiap kecamatan di Kabupaten Magelang. Economics Development Analysis Journal, 1(2).

Adisasmita, R. (2005). Dasar-dasar ekonomi wilayah. In Yogyakarta: Graha Ilmu.

Agénor, P.-R. (2010). A theory of infrastructure-led development. Journal of Economic Dynamics and Control, 34(5), 932-950. https://doi.org/10.1016/j.jedc.2010.01.009

Amalia, F. (2012). Penentuan sektor unggulan perekonomian wilayah Kabupaten Bone Bolango dengan pendekatan sektor pembentuk PDRB. Etikonomi, 11(2).

Arsyad, L. (2005). Pengantar Perencanaan Pembangunan Ekonomi Daerah. Edisi Kedua. Penerbit BPFE-UGM. Yogyakarta.

Bappeda Kab. Sumedang. (2016). Laporan Akhir Analisis Makro Ekonomi Kabupaten Sumedang dalam Perencanaan Pembangunan.

Hilmi, D. F., Hamzah, A., \& Syahnur, S. (2014). Analisis Sektor Basis Kabupaten Kota Dan Pusat Pengembangan Ekonomi Provinsi Jawa Barat. Jurnal Ilmu Ekonomi Pasca Sarjana Universitas Syah Kuala, 2(2), 50-61.

Ivankova, N. V., Creswell, J. W., \& Stick, S. L. (2006). Using Mixed-Methods Sequential Explanatory Design: From Theory to Practice. Field Methods, 18(1), 3-20. https://doi.org/10.1177/1525822X05282260

Kharisma, B., \& Hadiyanto, F. (2019). Analysis of Potential Sectors and Policy Priorities of Regional Economic Development in Maluku Province. ETIKONOMI, 18(1), 29-46. https://doi.org/10.15408/etk.v18i1.7440

Kuncoro, M. (2004). Otonomi \& Pembangunan Daerah. Erlangga.

Nasution, Z. (2020). Analisis Pengaruh Sektor Unggulan Menjadi Pusat Pertumbuhan Kabupaten Labuhanbatu Tahun 2013-2017. ECOBISMA (Jurnal Ekonomi, Bisnis Dan Manajemen), 7(1), 31-42. https://doi.org/10.36987/ecobi.v7i1.1526
Novita, D., \& Gultom, H. (2017). The Strategy of Economic Development Region Base on The Leading Sector at Kabupaten Langkat Provinsi Sumatera Utara. JASc (Journal of Agribusiness Sciences), $1(1), \quad 1-7$. https://doi.org/10.30596/jasc.v1i1.1540

Nugroho, I., \& Dahuri, R. (2016). Pembangunan Wilayah: Perspektif ekonomi, sosial dan lingkungan. LP3ES.

Paramita, A., \& Kristiana, L. (2013). Teknik Focus Group Discussion dalam Penelitian Kualitatif. Buletin Penelitian Sistem Kesehatan, 16(2), 117127. https://doi.org/10.22435/bpsk.v16i2

Ratnasari, E. D. (2014). Sectors analysis and determination of GDP forming leading sector in district Kebumen. Jurnal Fokus Bisnis, 13(01), $1-29$.

Risnawati, N. (2018). Profil UMK, Permasalahan, dan Upaya Pemberdayaannya di Kabupaten Sumedang. Coopetition, 9(1), 13 - 29. http://ikopin.ac.id/jurnal/index.php/coopetition/ar ticle/view/44

Robinson, T. (2005). Ekonomi Regional. In Jakarta. Bumi Aksara. Hal (Vol. 5).

Safwadi, I., \& Rangkuti, M. S. (2019). Analisis Struktur Ekonomi dan Sektor Unggulan Kabupaten Aceh Besar. Jurnal Humaniora: Jurnal Ilmu Sosial, Ekonomi Dan Hukum, 2(1), 39-48. https://doi.org/10.30601/humaniora.v2i1.52

Sapriadi, S., \& Hasbiullah, H. (2015). Analisis Penentuan Sektor Unggulan Perekonomian Kabupaten Bulukumba. Jurnal Iqtisaduna, 1(1), 53-71.

Todaro Michael, P., \& Smith, S. C. (2003). Pembangunan Ekonomi di Dunia Ketiga. edisi kedelapan. Erlangga, Jakarta.

Yulianita, A. (2009). Analisis Sektor Unggulan Dan Pengeluaran Pemerintah Di Kabupaten Ogan Komering Ilir. Jurnal Ekonomi Pembangunan, 8(2), 39-48. 
44 Coopetition, Vol XII, Nomor 1, Maret 2021, 31 - 44

(E-ISSN : 2615-4978, P-ISSN : 2086-4620) 